\title{
The phylogeny of Simulium (Chirostilbia) (Diptera: Simuliidae) and perspectives on the systematics of the genus in the Neotropical Region
}

\author{
Leonardo Henrique Gil-Azevedo ${ }^{1,2} /+$, Sixto Coscarón ${ }^{3}$, Marilza Maia-Herzog² \\ 1Departamento de Zoologia, Instituto de Biologia, Universidade do Estado do Rio de Janeiro, \\ Rua São Francisco Xavier 524, 20550-013 Rio de Janeiro, RJ, Brasil ²Laboratório de Simulídeos e Oncocercose, \\ Instituto Oswaldo Cruz-Fiocruz, Rio de Janeiro, RJ, Brasil ${ }^{3}$ Facultad de Ciencias Naturales y Museo, La Plata, Buenos Aires, Argentina
}

\begin{abstract}
Recently, knowledge of Neotropical Simuliidae has been accumulating quickly. However, information about supra-specific relationships is scarce and diagnoses of Simulium subgenera are unsatisfactory. To investigate the relationships among Simulium (Chirostilbia) species and test the subgenus monophyly, we performed a cladistic analysis. The ingroup included all species of this subgenus and the outgroup included representatives of the 17 species groups of Neotropical Simulium and three Holarctic species. The study was based on a data matrix with 31 terminal taxa and 45 morphological characteristics of adult, pupa and larva. The phylogenetic analysis under equal weights resulted in eight most-parsimonious trees (length $=178$, consistency index $=34$, retention index $=67$ ). The monophyly of the $\mathrm{S}$. (Chirostilbia) was not supported in our analysis. The Simulium subpallidum species group was closer to Simulium (Psilopelmia) and Simulium (Ectemnaspis) than to the Simulium pertinax species group. Additionally, we describe the three-dimensional shape of the terminalia of male and female of Simulium (Chirostilbia) for the first time and provide comments about the taxonomic problems involving some species of the subgenus: Simulium acarayense, Simulium papaveroi, S. pertinax, Simulium serranum, Simulium striginotum and S. subpallidum.
\end{abstract}

Key words: black fly - Culicomorpha - cladistics - morphology - taxonomy

Systematic knowledge of the Neotropical Simuliidae has been accumulating quickly and there are 351 valid Neotropical species (Coscarón et al. 2008, Adler \& Crosskey 2010, Hamada et al. 2010). Over the past 10 years, 67 taxonomic papers involving 20 researchers, as well as two extensive manuals, have been published (Coscarón \& Coscarón-Arias 2007, Shelley et al. 2010), resulting in the description of 18 new species (Adler \& Crosskey 2010, Hamada et al. 2010). Consequently, the Neotropical black fly became relatively well known and, unlike most of the other Neotropical animal taxa, a basic lack of data no longer is an issue (Rocha \& Boerger 2009).

Eleven subgenera of Simulium Latreille, 1802 have been found in the Neotropical Region (Adler \& Crosskey 2010). Most of the species in these subgenera are well described and well represented in institutional collections. However, knowledge of supraspecific group relationships is very scarce and subgenera diagnoses are unsatisfactory. In addition, there are problems in the delimitation of the identity of some species. As a result of these problems, divergent systematic arrangements exist in the literature (Py-Daniel \& Sampaio 1995, Coscarón et al. 2008, Adler \& Crosskey 2010, Shelley et al. 2010) and loose synonymies of species are often proposed, which tend to appear and disappear in the literature.

Financial support: $\mathrm{CNPq}$

+ Corresponding author: lhgazevedo@yahoo.com.br

Received 9 May 2011

Accepted 29 November 2011
In the literature, all systematic decisions were made exclusively based on personal opinions, without any clear methodology or hypothesis; as a result, one cannot rationally reject or accept the changes proposed. There have been a few morphological phylogeny studies, but they have not targeted major subjects such as the monophyly of subgenera, the relationship amongst the subgenera or the species identity (e.g., Coscarón \& Coscarón-Arias 1997, Strieder \& Py-Daniel 2002). In addition, there are limited molecular, cytogenetic and morphometric works dealing with Neotropical taxa (e.g., Coscarón-Arias 1998, Scarpassa \& Hamada 2003, Hamada et al. 2008, 2010). Therefore, the real problem underlying current Neotropical Simuliidae systematics is the organisation of the massive amount of data produced over the years.

Simulium (Chirostilbia) Enderlein, 1921 is a good case study because it is a group endemic to the Neotropics and has remained taxonomically stable. For example, no researchers have ever questioned the monophyly of the group; however, as with the other subgenera, the position of the group within Simulium is unknown and the diagnoses made for this group are too broad and are inadequate to clearly identify the subgenus (Coscarón 1981, Coscarón \& Coscarón-Arias 2007, Hernandez et al. 2008).

In the present study, a cladistic analysis was performed to test the monophyly of Simulium (Chirostilbia) and to evaluate the phylogenetic structure within the subgenus. We also provide comments about the taxonomic problems of some species of Simulium (Chirostilbia).

Historical background - Chirostilbia was created by Enderlein (1921a: 199) as a genus, with Chirostilbia flavifemur Enderlein, 1921, as the type species and was fully described by Enderlein in a different publication (1921b: 79). Subsequently, Chirostilbia was considered a subge- 
nus of Simulium (Pinto 1932) and Lane and Porto (1939) considered Simulium flavifemur as a synonym for Simulium pertinax Kollar, 1832. Coscarón (1981) established the subgenus, which contained five species. Coscarón (1982) proposed the Simulium subpallidum species group with three species later included in Simulium (Chirostilbia) (Coscarón 1987). He considered Simulium (Chirostilbia) to have two species groups: S. pertinax and S. subpallidum. Coscarón and Coscarón-Arias (1997) performed the only phylogenetic analysis of the subgenus, with 18 characters, 12 taxa in the ingroup and Simulium (Inaequalium) as the outgroup. Coscarón et al. (2008) considered 15 species in Simulium (Chirostilbia), 12 in S. pertinax and three in the S. subpallidum species group. The division into these species groups was contested by Hernández et al. (2008), who do not consider Coscarón's characters valid.

\section{MATERIALS AND METHODS}

Terminal taxa and specimens - The ingroup taxa consisted of all the species of Simulium (Chirostilbia) except for Simulium striginotum (Enderlein, 1933), which is known only by a female, for a total of 14 terminal taxa. The chosen outgroups were as follows: Metacnephia saileri (Stone, 1952), representatives of two Simulium subgenera from the Holarctic Region, Simulium (Hellichiella) nebulosum Currie \& Adler, 1986 and Simulium (Eusimulium) aureum Fries, 1824 and the 17 species groups of Neotropical Simulium recognised by Adler and Crosskey (2010).

The specimens studied herein are deposited in the following institutions: the Museo de La Plata (MLP) (Argentina), the Museu de Zoologia de São Paulo (Brazil), the Faculdade de Saúde Pública da Universidade de São Paulo (Brazil), the Coleção Histórica de Adolpho Lutz, Instituto Oswaldo Cruz (Brazil), the Coleção do Laboratório de Simulídeos e Oncocercose, Instituto Oswaldo Cruz (Brazil), the Instituto Nacional de Pesquisa da Amazônia (Brazil) and the Royal Ontario Museum (Canada). Whenever possible, we examined specimens of three developmental stages (larva, pupa and adult). The techniques used to prepare and observe the specimens and specimen-related material were previously described in Gil-Azevedo et al. (2005). Additionally, the preparations involved and the techniques used to observe the three-dimensional shape of the terminalia in a drop of glycerin on a depression slide were described in Adler et al. (2004).

Terminology and characters - We followed the morphological terminology of Adler et al. (2004), with the addition of terms from Gil-Azevedo and Maia-Herzog (2007). Based on an extensive morphological study, we identified the characters and proposed hypotheses of primary homology (Pinna 1991) (Supplementary data). The logic employed in the preparation of characters followed Sereno (2007). We codified these hypotheses in a data matrix using the program Mesquite (Maddison et al. 1997, Maddison \& Maddison 2007) (Supplementary data). Characters were preferentially coded reductively (Wilkinson 1995) and were treated as unordered (Fitch 1971). When two or more states of a character were found in one terminal taxon, the character was treated as polymorphic and both states were coded in the matrix.
Phylogenetic analyses - The dataset was analysed with maximum parsimony equal weights. The searches were carried out through heuristic algorithms. The parameters of the search were as follows: 3,000 replications and Tree bisection and reconnection with 1,000 trees saved per replication. The branch support was evaluated by bootstrap (Felsenstein 1985) with 5,000 replications by decay index (Bremer 1994), through the search of suboptimal trees and by a sensitivity analysis using analyses under implied weights (Goloboff et al. 2008b) $(\mathrm{k}=3,6,10,15,20,25)$. We used the TNT program for all searches (Goloboff et al. 2008a). Character optimisation, mapping and comparisons among the obtained trees were carried out with WinClada (Nixon 2002).

\section{RESULTS}

The data matrix was composed of 34 terminal taxa and 45 characters obtained from adult (25), pupa (12) and larva specimens of the last instar (8) (Supplementary data). The list of characters used in this analysis is given in Supplementary data.

The phylogenetic analysis under equal weights resulted in eight most-parsimonious trees with 178 steps, consistency index $=0.34$ and retention index $=0.67$ (Fig. 1, Table I). The obtained hypothesis indicates that Simulium (Chirostilbia) is not a monophyletic group because the $S$. subpallidum species group is closer to Simulium (Psilopelmia) Enderlein, 1934 + Simulium (Ectemnaspis) Enderlein, 1934, than to the S. pertinax species-group (Fig. 1). In spite of the low support from the bootstrap analysis and the decay index, the strict consensus tree has a good resolution and the clades are also found in the implied weights analyses (Fig. 1, Table II). We chose one of the shortest trees for character distribution and optimisation (Fig. 2).

Description of the terminalia of Simulium (Chirostilbia) based on a three-dimensional view - Female terminalia (Fig. 3): the hypogynial valves are small and subtriangular with slightly divergent external margins. The anal lobe is long and subtriangular, approximately 2.5 -fold longer than wide in the lateral view. The internal sides of the anal lobes are concave and facing each other, resembling a pair of long spoons. Therefore, when the anal lobe is fixated in a slide, it may either be wider and less curved or narrower and more curved, depending on whether the dorsal axis of the anal lobe is central or lateral, respectively (Hernandez et al. 2007, Figs 118, 121, respectively). The anal lobe is approximately three-fold longer than the cerci. The cerci are hemispheric and distinctly longer than wide in the lateral view. The internal sides of the cerci are concave and face each other like brackets. The genital fork stem is as long as the lateral arms and the spermatheca are oval; male terminalia (Fig. 4): the gonocoxites are subtrapezoidal to subquadrangular. The gonostyles are subtriangular and curved towards the aedeagus. In the $S$. subpallidum species group and Simulium jefersoni Hamada et al., 2006 the height of the gonostyle is distinctly longer than the base, whereas in the others the height and the base are similar sizes. The apical spur of the gonostyle is absent, but there is a sclerotized longitudinal ridge along the external border. The longitudinal ridge likely has the 
same function as the apical spur in other groups. The ventral plate is wider than it is long, with little curvature seen in profile, and is not very narrow apically. The median sclerite is widened with a strong median concavity. A dorsal sclerite is present as a sclerotized thin line. The paramere is elongated with developed teeth and connected to the apex of the ventral plate arms.

Below we give some remarks on some taxonomic species of Simulium (Chirostilbia).

The S. pertinax Kollar, 1832 has a complex taxonomic history, as explained in Shelley et al. (1984), but is not particularly complicated taxonomically, as suggested by Hernandez et al. (2008). There are six junior synonyms of $S$. pertinax, but these are easily explained. This species has a continental distribution and is a vicious human biter; as a result, it is easy to find and has been collected by different and isolated authors, who went on to describe it as a new species. S. pertinax is homogeneous based on morphological (Gil-Azevedo et al. 2004) and cytological (Campos et al. 1996, 2001) data and there is no reference in the literature to delimitation problems for this species. Such problems are common for other Simulium species (e.g., $S$. subpallidum Lutz, 1910 and Simulium incrustatum Lutz, 1910). Hernandez et al. (2008) recorded this species in Bo-

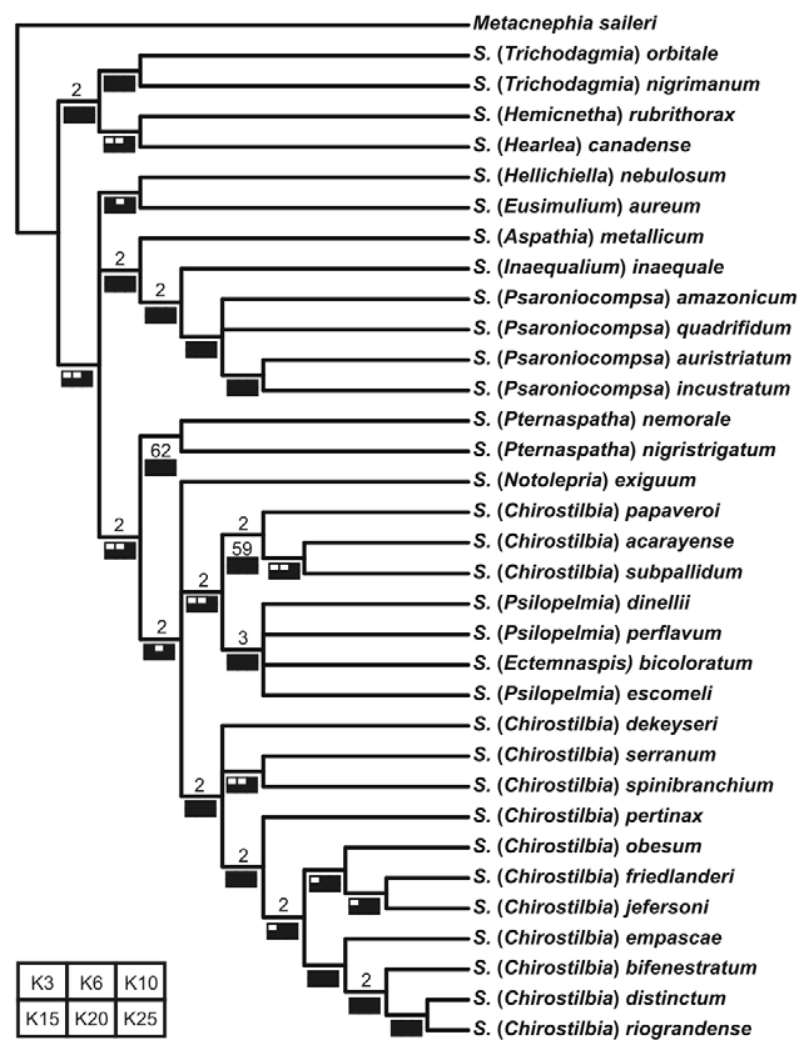

Fig. 1: reconstructed phylogeny of Simulium (Chirostilbia). Strict consensus of the eight most parsimonious trees resulted from the analysis under equal weights, with 178 steeps (consistency index $=0.34$, retention index $=0.67$ ). Branch support: decay index (up) and bootstrap (down). Decay index below two and bootstrap below $50 \%$ are not shown. The boxes represent the permanence of the clades in the analyses under implied weights with different concavities $(\mathrm{k}=3,6,10,15,20,25)$. livia (north of Santa Cruz; 16.V.1989, JJ McGrande coll.) based only on two biting females. We did not consider this a valid occurrence because those females could have been from any Simulium (Chirostilbia) species and we prefer to wait until someone collects additional exemplars associated with pupae to confirm this occurrence.

Simulium serranum Coscarón, 1981 - Originally, Coscarón (1981) named this species S. serranus, but Simulium is neutral in gender and serranus is an adjective in the masculine form. According to the International Code of Zoological Nomenclature, the species-group name should agree in gender with the genus (ICZN 1999: 31.2 ); thus, the corrected name is now $S$. serranum.

Hernandez et al. (2007) observed the holotype of $S$. striginotum (Enderlein, 1933) [1 female, Bolivia, Department of La Paz, Mapiri, Sarampione (14.II.1903)] and synonymised this species with Simulium spinibranchium based on the scutum colouration, morphology of the cibarium, nudiocular area, wing setation, leg colouration and the structure of the genitalia, especially the cercus and anal lobe. We do not accept this synonymy because the colouration of exemplars collected over a century ago is not reliable. In addition, wing setation and the structures of genitalia are very similar in all Simulium (Chirostilbia) species. Moreover, the Department of La Paz is located in the Bolivian Altiplano, at a high altitude and very far from locations associated with any records of Simulium (Chirostilbia) species; therefore, this is likely a valid separate species. Although we agree with Hernandez et al. (2007) that this species is most likely within the $S$. pertinax species group of $S$. (Chirostilbia), it is necessary to collect fresh material of all stages at the type-locality to define the identity of the species properly.

Hernandez et al. (2007) synonymised Simulium acarayense Coscarón \& Wygodzinsky, 1972 with S. subpallidum and we agree that there is only one distinctive character between both species, the scutum colouration, but the species also differ in pupal and larval continuous characters that are related to environmental variables: the length of the pupal gill, the number of rays in the

\section{TABLE I}

Number of most parsimonious trees (MPTs), length, consistency index (CI), retention index (RI) and fit from trees found in the analyses, with equal weights (EW) and implied weights (IW)

\begin{tabular}{lcccc}
\hline Analysis & MPTs & Length & CI/RI & Fit \\
\hline EW & 8 & 178 & $0.34 / 0.67$ & - \\
IW k3 & 2 & 183 & $0.33 / 0.66$ & 17.94 \\
IW k6 & 6 & 180 & $0.33 / 0.67$ & 12.16 \\
IW k10 & 1 & 178 & $0.34 / 0.67$ & 8.56 \\
IW k15 & 2 & 178 & $0.34 / 0.67$ & 6.25 \\
IW k20 & 2 & 178 & $0.34 / 0.67$ & 4.92 \\
IW k25 & 2 & 178 & $0.34 / 0.67$ & 4.07 \\
\hline
\end{tabular}


TABLE II

Differences between Simulium pertinax and Simulium subpallidum species-groups based on characters of the cladistic analyses

Characters

Claw sub-basal tooth

Abdomen, general colouration

Male terminalia, length ratio gonostyle/gonocoxite

Larval antenna, segment 3

Larval hypostoma, anterior margin

Larval post genal cleft

Cocoon, shape

S. pertinax species group

Present

Dark colour

Gonocoxite distinctly greater ${ }^{a}$

Equal to or shorter than $2^{b}$

Straight $^{c}$

Subtriangular

Boot-shaped or intermediate
S. subpallidum species group

Absent

Light colour

Equal or gonostyle greater

Longer than 2

Concave

Oval

Clearly shoe-shaped

a: except Simulium jefersoni; b: except Simulium serranum, Simulium spinibranchium and S. jefersoni; $c$ : except S. serranum and Simulium bifenestratum.

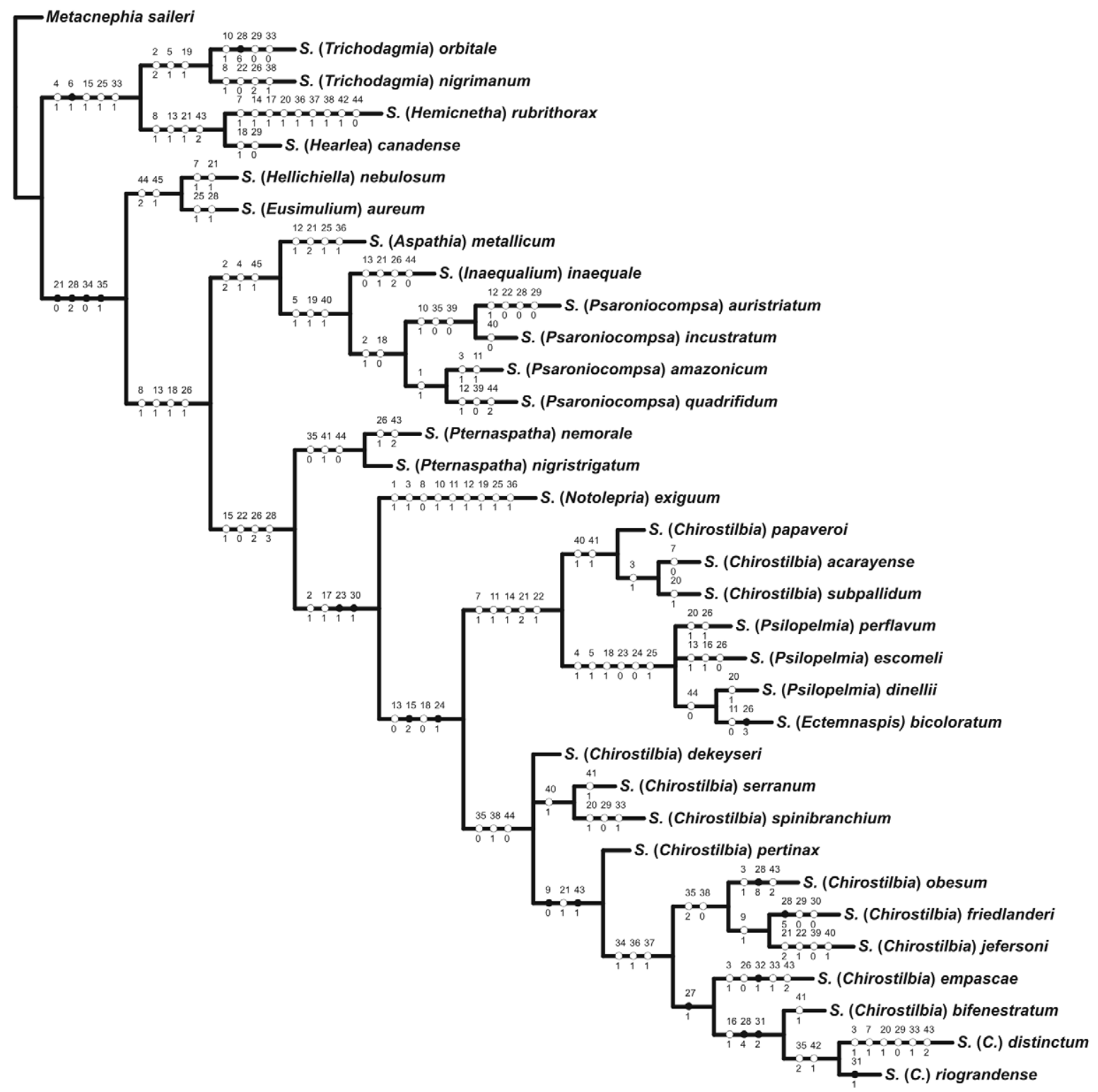

Fig. 2: one of eight trees obtained with maximum parsimony chosen to represent the character distribution. Circles represents apomorphies (white: homoplastic; black: no homoplastic). The numbers above the circles represent characters and the numbers below refer to character states. Character with ambiguous optimization: 18, 24, 26 and 33: ACCTRAN; 8, 11, 38, 39, 45: DELTRAN. 
larval cephalic fan, the number of hook rows of the larval anal ring and the number of lobes in the larval rectal papillae. We accept this synonymy for now, but future works based on morphometry, molecular or cytological data are necessary to properly define the identity of the species.

Hernandez et al. (2008) indicate that Simulium papaveroi Coscarón, 1982 is morphologically similar to Simulium dekeyseri Shelley \& Py-Daniel, 1981 and S. serranum based only on a few female and pupal characters, mainly scutum colouration, female terminalia and pupal gills. These characters are very similar in all species of Simulium (Chirostilbia) sensu lato and likely for this reason, these authors did not recognise the $S$. subpallidum species group. However, a careful observation of the specimen characters, including male terminalia, pupal cocoons and larval heads, indicates that this species is closer to S. subpallidum.

\section{DISCUSSION}

The monophyly of the Simulium (Chirostilbia) was not supported in our analysis because the $S$. subpallidum species group was closer to Simulium (Psilopelmia) Enderlein, 1934 + Simulium (Ectemnaspis) Enderlein, 1934 than to the $S$. pertinax species group (Figs 1, 2). These analytical results may explain the weak diagnoses of the subgenus throughout the literature (e.g., Coscarón 1981, 1991, Hernandez et al. 2008). These results also indicate the importance of performing cladistic analyses in taxa reviews, especially when proposing systematic changes. Based on our data, we see two possibilities: restricting Simulium (Chirostilbia) to the S. pertinax species group and creating a new subgenus for the $S$. subpallidum species group, or including and synonymising Simulium (Psilopelmia) and Simulium (Ectemnaspis) with Simulium (Chirostilbia). We believe the second option is preferable, but our analyses do not have enough bootstrap or Bremer support to make us comfortable proposing these changes at this time. A more complete analysis of Simulium is necessary before implementing a deeper rearrangement of Simulium subgenera.

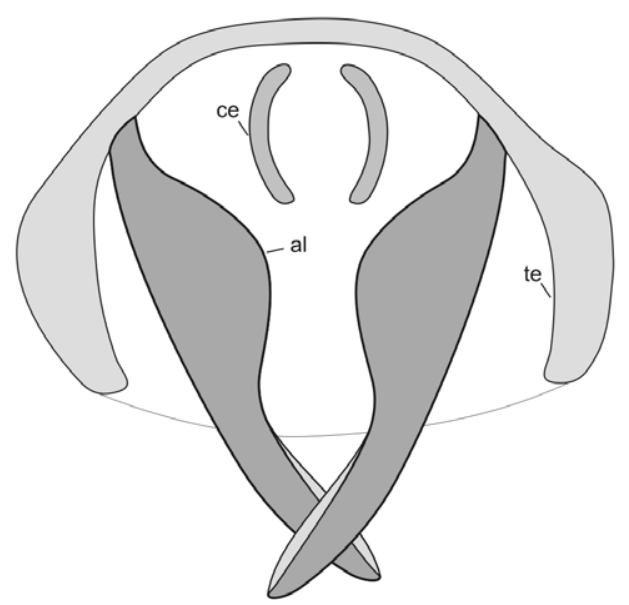

Fig. 3: scheme of female terminalia of Simulium (Chirostilbia) in ventrodistal view. al: anal lobe; ce: cerci; te: tergite.
The division of $S$. (Chirostilbia) into species groups, as proposed by Coscarón (1991), was contested by Hernandez et al. (2008). The latter authors argue that "the species do not clearly fit into groups because of the variation and overlap of morphological characters, especially the colouration of the thorax and the form of the male gonostyle" (Hernandez et al. 2008). We agree that these two characters do not justify the species groups; however, Hernandez et al. (2008) ignore other characters, such as sub-basal claw teeth, cocoon shape and larval head characters that differentiate the species groups (Table II). In fact, our analyses indicate that the two groups are monophyletic and may not be sister groups (Figs 1,2).

The $S$. pertinax species group was recovered in all of our analyses. In our basal branches, the resolution is poor and the relationship amongst $S$. dekeyseri, S. serranum, $S$. spinibranchium and the major branch requires further investigation. However, the resolution within the major branch is clear. The major branch presents, as synapomorphies, female scutum patterns with blurred stripes, a male gonostyle more than two-thirds the length of the gonocoxite and larvae with $8+8$ hypostomal setae or more. S. pertinax is in the base of the major branch opposed to the group formed by boot-shaped cocoon species (the only exception is Simulium bifenestratum Hamada \& Pepinelli, 2004 that has a highly derivative cocoon and was treated as inapplicable for this character). Inside the boot-shaped cocoon clade, there are two branches: (Simulium obesum Vulcano, 1959 (Simulium friedlanderi Py-Daniel, $1987+$ S. jefersoni)) and (Simulium empascae Py-Daniel, Souza \& Caldas, 1988 (S. bifenestratum (Simulium distinctum Lutz, 1910 + Simulium riograndense Py-Daniel, Souza \& Caldas, 1988))). The synapomorphies of these branches are as follows: the larvae with positive apoteme and cocoon fabric with visible thick threads are synapomorphic with the first branch and the pupa with cephalic trichomes that are small and thin and are synapomorphic with the second. In addition, the clade (S. bifenestratum (S. dis-

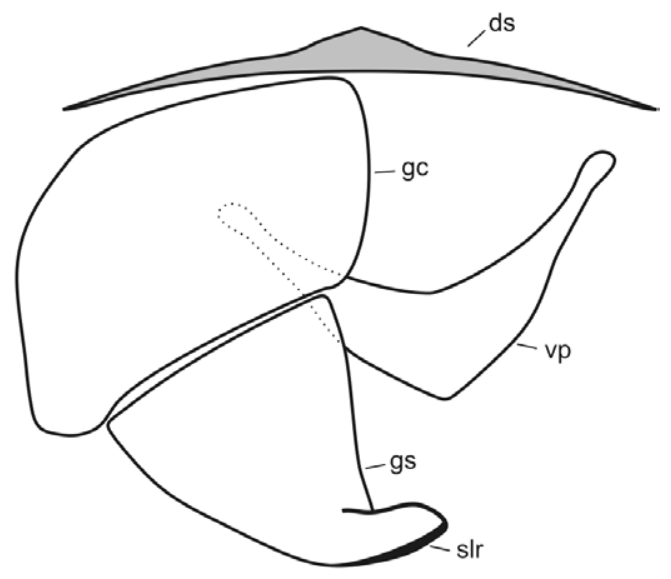

Fig. 4: scheme of male terminalia of Simulium (Chirostilbia) in ventrodistal view. ds: dorsal sclerite; gc: gonocoxite; gs: gonostyle; slr: sclerotized longitudinal ridge; vp: ventral plate. 
tinctum + S. riograndense)) is well defined and presents three synapomorphies: female with the distal apex of the anal lobe pointed, pupal gill with 10 filaments and gill filaments arrangement two-dimensionally and forming an almost complete circle.

Our tree is similar to the tree found by Coscarón and Coscarón-Arias (1997). Both trees recovered the $S$. pertinax and S. subpallidum species-groups, but the 1997 paper did not test the Simulium (Chirostilbia) monophyly because only one outgroup, Simulium (Inaequalium) Coscarón \& Wygodzinsky, 1984, was used. In addition, the 1997 tree indicates two distinct clades in the $S$. pertinax species group: $S$. dekeyseri (as Simulium laneportoi Vargas, 1941) + S. pertinax $+S$. serranum + $S$. spinibranchium, and $S$. distinctum $+S$. empascae $+S$. friedlanderi $+S$. obesum $+S$. riograndense. However, our tree presents the first group as paraphyletic and the second with more resolution. These differences may result from the inclusion of more characters (45 against 18 for the 1997 tree) and the inclusion of the more recently described taxa, S. bifenestratum and S. jefersoni.

The representatives of the Neotropical Simulium subgenera were used here to test the monophyly of Simulium (Chirostilbia). However, the trees obtained provide insights about the relationships among these subgenera. Some groups were formed with large numbers of non-ambiguous synapomorphies and were recovered in implied weights analyses. We comment on these clades following.

Simulium (Hearlea) + Simulium (Hemicnetha) + Simulium (Trichodagmia) - Simulium (Hemicnetha) Enderlein, 1934 and Simulium (Hearlea) Vargas, Martínez Palacios \& Díaz Nájera, 1946, were synonymised by Adler et al. (2004) based on a phylogeny of Nearctic simuliids. Shelley et al. (2010) proposed the synonymy of both with Simulium (Trichodagmia) Enderlein, 1934, based on Enderlein's papers (1934a, b, 1936) but did not discuss more modern definitions of the subgenera (e.g., Coscarón 1991, Miranda-Esquivel 2001). The group was recovered in our phylogeny with five synapomorphies (Fig. 2) and it is likely that these subgenera are closely related. Moreover, some Afrotropical Simulium subgenera, such as Simulium (Anasolen) Enderlein, 1930, Simulium (Freemanellum) Crosskey, 1969, and Simulium (Xenosimulium) Crosskey, 1969 are likely also related to this clade (Miranda-Esquivel \& Coscarón 2001) and an analysis with all Simulium subgenera is necessary to test these hypotheses.

Simulium (Inaequalium) + Simulium (Psaroniocompsa) - Shelley et al. (2010) proposed the synonymy of Simulium (Psaroniocompsa) Enderlein, 1934 and Simulium (Inaequalium) based on their personal opinion concerning the characters of the original diagnosis of Simulium (Inaequalium) (“... none is considered by us to be of subgeneric value."). Simulium (Inaequalium) and Simulium (Psaroniocompsa) are sister groups, as proposed by Coscarón and Wygodzinsky (1984), and were recovered here with three synapomorphies (Fig. 2). Both subgenera are very distinct and have an easily recognisable morphology. We also disagree that there are "good or bad" characters for specific hierarchical categories. Therefore, we think that this synonymy is unnecessary.

Simulium (Notolepria) $+[$ Simulium $($ Psilopelmia $)+$ Simulium (Ectem-naspis) + Simulium (Chirostilbia)] The relationship amongst these subgenera has not been proposed before and the group has four synapomorphies (Fig. 2). The clade Simulium (Chirostilbia) + Simulium $($ Psilopelmia $)+$ Simulium (Ectemnaspis) presents four synapomorphies (Fig. 2) and brings back a forgotten issue in the Neotropical black fly history. Stone (1963) proposed the synonymy of Chirostilbia and Ectemnaspis based on similarities of female terminalia of the type species; Wygodzinsky (1971) argued that the species were quite different when comparing male and pupa but stressed that the "Ectemnaspis-Chirostilbia complex", as he denominated it, needed further investigation. We agree with that suggestion.

In the literature, there is no consensus regarding the limits of Simulium (Psilopelmia) and Simulium (Ectemnaspis) (Coscarón et al. 2008, Adler \& Crosskey 2010) and Shelley et al. (2010) proposed the synonymy of both based on that. In our phylogeny, these species groups were recovered as a monophyletic group with four synapomorphies and Simulium (Psilopelmia) was paraphyletic without Simulium (Ectemnaspis), corroborating their synonymy. However, it is still necessary to examine the relationship between the group and Simulium (Psilozia) Enderlein, 1936 (Adler et al. 2004).

Some characters that have been traditionally used in the systematic classification of Neotropical simuliids were tested in the present analysis, including the scutum colouration of adults, the number of branches of pupal trichomes and the number of hypostomal setae of larvae. The phylogenetic signal of these characters was weak, with low consistency and retention indexes. Thus, these characters are not reliable for defining groups and require further investigation.

Many systematic problems in the Neotropical Simulium species are still unsolved and the traditional morphology seems to be inconclusive in some respects. A broad approach is important, using chromosomal, molecular biology and morphology data, as has been shown in the studies of Nearctic Simulium (Adler et al. 2004). Studies using these techniques are incipient in Neotropical Region and this needs to change. At the same time, the morphological studies in the region have not been fully explored. For example, in the present work, a threedimensional view of a Neotropical Simuliidae terminalia was described for the first time, a character that has been used for Nearctic fauna since the 1970s. In addition, studies using scanning electron microscopy and/or morphometry in the region are rare.

Whatever the tool used, systematic changes must be grounded in a methodology, whether cladistic or probabilistic. Systematics without a basic methodology and based on key features or personal opinion only lead us into a vicious circle. Such systematics proposals are not based on a clear method and lack hypotheses. Therefore, they cannot be rejected or corroborated by other researchers and need to be avoided. 


\section{ACKNOWLEDGEMENTS}

To Dr Neusa Hamada and Dr Victor Py-Daniel (INPA) and Douglas Currie (ROM), that kindly permitted access to their respective collections and donated additional material, to Dr Amanda Mendes (MN-UFRJ) and the two anonymous rewires that contributed many thoughtful suggestions that improved this work.

\section{REFERENCES}

Adler PH, Crosskey RW 2010. World blackflies (Diptera: Simuliidae): a comprehensive revision of the taxonomic and geographical inventory [monograph on the internet]. Clemson University. [cited 2010 Dec 13]. Available from: entweb.clemson.edu/biomia/pdfs/ blackflyinventory.pdf.

Adler PH, Currie DC, Wood DM 2004. The blackflies (Simuliidae) of North America, Cornell University Press, New York, 960 pp.

Bremer K 1994. Branch support and tree stability. Cladistics 10: 295-304.

Campos J, Andrade CFS, Recco-Pimentel SM 2001. Chromosomal comparisons among and within populations of Simulium (Chirostilbia) pertinax (Diptera, Simuliidae). Mem Inst Oswaldo Cruz 96: 365-369.

Campos J, Recco-Pimentel SM, Andrade CFS 1996. Polyten chromosome analysis of a population of Simulium pertinax (Diptera: Simuliidae). Rev Bras Genet 19: 47-52.

Coscarón S 1981. Notas sobre simúlidos Neotropicais. XI. Sobre el subgênero Simulium (Chirostilbia) Enderlein, con la descripcíon de dos especies nuevas del S.E. del Brasil (Diptera, Insecta). Rev Soc Entomol Argent 40: 157-164.

Coscarón S 1982. Notas sobre simulidos Neotropicales X. Sobre un grupo peculiar de especies del genero Simulium del S.E. de Brasil, Paraguay y N.O. de Argentina (Diptera-Insecta). Rev Soc Entomol Argent 41: 65-76.

Coscarón S 1987. El genero Simulium Latreille en la región Neotropical: análisis de los grupos supraespecificos, especies que los integran y distribución geográfica (Simuliidae, Diptera, Insecta), Museu Paraense Emilio Goeldi, Belém, 111 pp.

Coscarón S 1991. Fauna de agua dulce de la Republica Argentina 38. Insecta, Diptera, Simuliidae, Fasc. 2, Fundación para la Educación, la Ciencia y la Cultura, Buenos Aires, 304 pp.

Coscarón S, Coscarón-Arias CL 1997. Cladistic analysis of the subgenera Inequalium, Psaroniocompsa and Chirostilbia of the genus Simulium with comments on their distribution. Rev Soc Entomol Argent 56: 109-121.

Coscarón S, Coscarón-Arias CL 2007. Neotropical Simuliidae (Diptera: Insecta). In J Adis, JR Arias, G Rueda-Delgado, KM Wantzen, Aquatic biodiversity in Latin America (ABLA), Vol. 3, Pensoft, Sofia-Moscow, 685 pp.

Coscarón S, Coscarón-Arias CL, Papavero N 2008. Catalogue of Neotropical Diptera. Simuliidae. Neotrop Diptera 2: 1-90.

Coscarón S, Wygodzinsky P 1984. Notas sobre simúlidos Neotropicales. VII. Sobre los subgêneros Psaroniocompsa Enderlein e Inaequalium subgén. nov. Arq Zool 31: 37-103.

Coscarón-Arias CL 1998. The polytene chromossomes of Cnesia dissimilis (Edwards) and three species of Gigantodax Enderlein (Diptera: Simuliidae) from Lanin National Park (Argentina). Mem Inst Oswaldo Cruz 93: 445-458.

Crosskey RW 1990. The natural history of blackflies, John Wiley, Chichester, $711 \mathrm{pp}$.

Enderlein G 1921a. Das System der Kriebelmücken (Simuliidae). Dtsch tierarztl wochenschr 29: 197-200.
Enderlein G 1921b. Die Systematische Gliederung der Simuliiden. Zool Anz 3: 43-46.

Enderlein G 1934a. Weiterer Ausbau des Systems der Simuliiden (Dip.). Dtsch entomol z 1933: 273-292.

Enderlein G 1934b. Aussereuropäische Simuliiden aus dem Wiener Museum. Sitz ber Ges Nat forsch Freunde Berl 1934: 190-195.

Enderlein G 1936. Simuliologica I. Sitz ber Ges Nat forsch Freunde Berl 1936: 114-130.

Felsenstein J 1985. Confidence limits on phylogenies: an approach using the bootstrap. Evolution 39: 783-791.

Fitch WN 1971. Toward defining the course of evolution: minimum change for a specified tree topology. Syst Zool 20: 406-416.

Gil-Azevedo LH, Figueiró R, Maia-Herzog M 2005. Simulium (Psaroniocompsa) stellatum (Diptera: Simuliidae), a new black fly from a high mountain range in southeastern Brazil. Zootaxa 922: 1-12.

Gil-Azevedo LH, Maia-Herzog M 2007. Preliminary considerations on phylogeny of Simuliidae genera from Southern Hemisphere (Insecta-Diptera). Zootaxa 1643: 39-68.

Gil-Azevedo LH, Santos-Mallet JR, Maia-Herzog M 2004. Caracteres diagnósticos de Simulium (Chirostilbia) pertinax (Diptera, Simuliidae). Neotrop Entomol 33: 433-437.

Goloboff P, Carpenter J, Salvador-Arias J, Miranda-Esquivel DR 2008a. Weighting against homoplasy improves phylogenetic analysis of morphological data sets. Cladistics 24: 758-773.

Goloboff P, Farris J, Nixon K 2008b. TNT, a free program for phylogenetic analysis. Cladistics 24: 774-786.

Hamada N, Pepinelli M, Mattos-Glória A, Luz SLB 2010. A new black fly species from Brazil, closely related to Simulium guianense Wise (Diptera, Simuliidae), revealed by morphology and DNA barcoding. Zootaxa 2428: 22-36.

Hamada N, Pereira ES, Adler PH 2008. Polytene chromosomes of Simulium (Psaroniocompsa) daltanhani (Diptera: Simuliidae) from Central Amazonia. Zootaxa 1676: 57-62.

Hernández LM, Shelley AJ, Luna-Dias APA, Maia-Herzog M 2007. New specific synonymies and taxonomic notes in Neotropical blackflies (Diptera: Simuliidae) belonging to the subgenera Chirostilbia Enderlein, Hemicnetha Enderlein, Inaequalium Coscarón \& Wygodzinsky, Psaroniocompsa Enderlein and Psilopelmia Enderlein. Zootaxa 1580: 1-80.

Hernández LM, Shelley AJ, Luna-Dias APA de, Maia-Herzog M 2008. Review of the Neotropical blackfly subgenus Chirostilbia Enderlein (Diptera: Simuliidae) based on adults and pupal morphology. Zootaxa 1834: 1-100.

ICZN - International Commission on Zoological Nomenclature 1999. International code of zoological nomenclature, 4th ed., International Trust for Zoological Nomenclature, London. Available from: nhm.ac.uk/hosted-sites/iczn/code/.

Lane J, Porto CE 1939. Simulídeos da Região Neotrópica. O gênero Eusimulium. Boletim Biologico 4: 168-176.

Maddison DR, Swofford DL, Maddison WP 1997. NEXUS: an extensible file format for systematic information. Syst Biol 46: 590-621.

Maddison WP, Maddison DR 2007. Mesquite: a modular system for evolutionary analysis, v. 2.01 [software on the Internet]. Published by the authors; [cited 2010 Dec 13]. Available from: mesquiteproject.org.

Miranda-Esquivel DR, Coscarón S 2001. Cladistic analysis of Simulium (Trichodagmia) and Simulium (Thyrsopelma) (Diptera: Simuliidae). Zool J Linn Soc 132: 429-439. 
Nixon KC 2002. WinClada, v. 1.00.08. [software on the Internet]. Published by the author; 2002 [cited 2009 Jan 08]. Available from: cladistics.com.

Pinna MCC de 1991. Concepts and tests of homology in the cladistic paradigm. Cladistics 7: 367-394.

Pinto C 1932. Simuliidae da América Central e do Sul (Diptera). Resumos da $7^{a}$ Reunión de la Sociedad Argentina de Patologia de la Región Norte 60: 661-763.

Py-Daniel V, Sampaio RTM 1995. Gêneros e espécies de Simuliidae (Diptera: Culicomorpha) assinalados para o Brasil até 1995. Entomol Vect 5: 117-121.

Rocha RM da, Boerger WAP 2009. Estado da arte e perspectivas para a zoologia no Brasil, Editora UFPR, Curitiba, 296 pp.

Scarpassa VM, Hamada N 2003. Isozyme variation on four species of the Simulium perflavum species group (Diptera: Simuliidae) from the Brazilian Amazon. Genet Mol Biol 26: 39-46.

Sereno P 2007. Logical basis for morphological characters in phylogenetics. Cladistics 23: 565-587.
Shelley AJ, Hernandez LM, Maia-Herzog M, Luna-Dias, APA, Garritano PR 2010. The blackflies (Diptera: Simuliidae) of Brazil. In JR Arias, S Golovatch, KM Wantzen, E Domínguez, Eds., Aquatic biodiversity in Latin America (ABLA), Vol. 6, Pensoft, Sofia-Moscow, $821 \mathrm{pp}$.

Shelley AJ, Luna-Dias APA, Maia-Herzog M 1984. New specific synonymy in Neotropical Simulium s.l. (Diptera: Simuliidae). Mem Inst Oswaldo Cruz 79: 143-161.

Stone A 1963. An annoted list of genus-group names in the family Simuliidae (Diptera). USDA Technical Bulletins 1284: 1-28.

Strieder MN, Py-Daniel V 2002. A cladistic analysis of Inaequalium (Coscarón \& Wygodzinsky, 1984), with information on geographical distribution (Diptera: Simuliidae). Mem Inst Oswaldo Cruz 97: 65-72.

Wilkinson M 1995. A comparison of two methods of character reconstruction. Cladistics 11: 297-308.

Wygodzinsky P 1971. Descriptions and redescriptions of species of the blackfly genus Simulium from the Northern Andes (Simuliidae, Diptera). Am Mus Novit 2447: 1-38. 
Character list

\begin{tabular}{|c|c|c|c|c|c|}
\hline & Characters and states & $\mathrm{L}$ & $\mathrm{CI}$ & RI & Summary \\
\hline \multicolumn{6}{|c|}{ Adult - female } \\
\hline 1 & Nudiocular area: (0) present; (1) absent. & 2 & 0.50 & 0.50 & Cited by Coscarón (1987). \\
\hline 2 & $\begin{array}{l}\text { Mandible teeth: (0) well developed in both sides; (1) developed } \\
\text { in the internal side and scarce developed on external side; } \\
\text { (2) developed just on the internal side. }\end{array}$ & 4 & 0.50 & 0.77 & Modified from character 7 of Gil-Azevedo and Maia-Herzog (2007: 43). \\
\hline 3 & $\begin{array}{l}\text { Palp, ration between the length of the segments IV and } \\
\text { V: (0) V about twice or more than the IV; (1) V distinctly } \\
\text { shorter than the double of the IV. }\end{array}$ & 7 & 0.14 & 0.14 & Character 8 of Gil-Azevedo and Maia-Herzog (2007: 43). \\
\hline 4 & $\begin{array}{l}\text { Cibarium, anteromedial border, colouration: }(0) \text { unpigmented } \\
\text { or slightly pigmented; (1) distinctly pigmented. }\end{array}$ & 3 & 0.33 & 0.84 & Cited by Coscarón (1987). \\
\hline 5 & $\begin{array}{l}\text { Cibarium, anteromedial border, surface: } \\
\text { (0) unarmed; (1) distinctly armed }{ }^{a} \text {. }\end{array}$ & 3 & 0.33 & 0.80 & Character 203 of Adler et al. (2004: 157). \\
\hline 6 & $\begin{array}{l}\text { Cibarium, arms, shape: }(0) \text { large, about two times } \\
\text { longer than wide; (1) short, as long as wide. }\end{array}$ & 1 & 1.00 & 1.00 & - \\
\hline 7 & $\begin{array}{l}\text { Thorax, scutum, colouration: ( } 0 \text { ) dark colour - black to dark brown; } \\
\text { (1) light colour - light brown to yellow. }\end{array}$ & 5 & 0.20 & 0.50 & $\begin{array}{c}\text { Modified from character } 1 \text { and } 3 \text { of Coscarón and Coscarón-Arias (1997: 114) } \\
\text { and character } 12 \text { of Gil-Azevedo and Maia-Herzog (2007: 43). }\end{array}$ \\
\hline 8 & $\begin{array}{l}\text { Thorax, scutum, pattern: }(0) \text { absent; (1) adorned } \\
\text { with silvery spots and/or stripes. }\end{array}$ & 4 & 0.25 & 0.25 & Cited by Coscarón (1987). \\
\hline 9 & Thorax, scutum, pattern, stripes definition: (0) blurred; (1) well-marked. & 2 & 0.50 & 0.80 & - \\
\hline 10 & Thorax, scutum, hairs, distribution: (0) homogeneous; (1) in groups (tuft). & 3 & 0.33 & 0.33 & Character 2 of Coscarón and Coscarón-Arias (1997: 113). \\
\hline 11 & Hind leg, basal or sub-basal tooth: (0) present; (1) absent. & 4 & 0.25 & 0.57 & $\begin{array}{l}\text { Character } 5 \text { of Coscarón and Coscarón-Arias (1997: 114) and } 142 \\
\text { of Adler et al. (2004: 152) and } 17 \text { of Gil-Azevedo and Maia-Herzog (2007: 44). }\end{array}$ \\
\hline 12 & Wing, vein $\mathrm{Sc}_{2}$ setae: (0) present; (1) absent. & 4 & 0.25 & 0.00 & Character 15 of Miranda-Esquivel and Coscarón (2001: 430). \\
\hline 13 & Wing, basal sector of the vein R, setae: (0) present; (1) absent. & 5 & 0.20 & 0.60 & $\begin{array}{l}\text { Character } 4 \text { of Coscarón and Coscarón-Arias (1997: 114) } \\
\text { and } 24 \text { of Gil-Azevedo and Maia-Herzog (2007: 45). }\end{array}$ \\
\hline 14 & $\begin{array}{l}\text { Abdomen, general colouration: ( } 0 \text { ) dark colour - black to dark brown; } \\
\text { (1) light colour - light brown to yellow. }\end{array}$ & 2 & 0.50 & 0.85 & Cited by Coscarón (1987). \\
\hline 15 & $\begin{array}{l}\text { Anal lobe, shape: (0) hemispheric with curved distal border; } \\
\text { (1) sub-square; (2) triangular and base smaller than high. }\end{array}$ & 3 & 0.66 & 0.92 & $\begin{array}{l}\text { Modified from character } 6 \text { of Coscarón and Coscarón-Arias (1997: 114) and } \\
18 \text { of Miranda-Esquivel and Coscarón (2001: 430). }\end{array}$ \\
\hline 16 & $\begin{array}{l}\text { Triangular anal lobe, distal apex, } \\
\text { shape: (0) blunt; (1) pointed. }\end{array}$ & 2 & 0.50 & 0.66 & Cited by Coscarón (1991). \\
\hline 17 & Anal lobe, internal border, shape: (0) straight or convex; (1) concave. & 2 & 0.50 & 0.92 & Cited by Coscarón (1991). \\
\hline 18 & $\begin{array}{l}\text { Genital fork, shape: }(0) \text { stem as long as lateral arms; } \\
\text { (1) stem about twice longer } \\
\text { or more than lateral arms. }\end{array}$ & 5 & 0.20 & 0.55 & Character 36 of Gil-Azevedo and Maia-Herzog (2007: 48). \\
\hline 19 & Spermatheca, shape: (0) oval, (1) spherical. & 3 & 0.33 & 0.71 & Character 37 of Gil-Azevedo and Maia-Herzog (2007: 48). \\
\hline
\end{tabular}


20 Scutum, colouration: (0) dark colour - black to dark brown; (1) light colour - light brown to yellow.

21 Male terminalia, length ratio between gonostyle and gonocoxite: (0) gonostyle less than $2 / 3$ of gonocoxite; (1) gonostyle more than $2 / 3$ of gonocoxite but distinctly smaller than gonocoxite; (2) gonostyle about as long as the gonocoxite to distinctly greater.

22 Gonostylus, length ratio between height and base: (0) similar sizes; (1) the height distinctly longer than base.

23 Gonostylus, apex, spurs: (0) present; (1) absent or very reduced.

24 Gonostylus, longitudinal ridge: (0) absent; (1) present

25 Ventral plate, median keel projected apically: (0) absent; (1) present.

26 Pupal trichomes, branches [number (maximum)]: (0) 1 ; (1) 2 ; (2) 3-6; (3) 25-40

27 Cephalic trichomes, shape: (0) large and thick; (1) small and thin.

28 Gill filaments (number): (0) 2-3; (1) 4; (2) 6; (3) 8 ;

(4) 10 ; (5) $11 ;(6) 12 ;(7)$ about 20; (8) about 120.

29 Gill filaments, shape: (0) thick; (1) thin.

30 Gill filaments, arrangement, spatial distribution: (0) three-dimensional; (1) two-dimensional.

31 Gill filaments, two-dimensional branch, arrangement: (0) about 1/4 of a circle; (1) about a semi-circle; (2) almost a whole circle.

32 Gill, main-branch, base, spines: (0) absent; (1) present.

33 Abdominal tergites, rows of short spines: (0) present; (1) absent.

34 Cocoon, shape in lateral view: (0) slipper-shaped (anterior opening next to the substratum); (1) boot-shaped (anterior opening separated from substratum, upward directed $)^{b}$.

35 Cocoon, fabric, structure: (0) homogeneous without distinct threads; (1) with visible fine threads; (2) with visible thick threads.

36 Cocoon, anterior rim, shape: (0) thickened; (1) not thickened.

37 Cocoon, extension: (0) covering partially the thorax and gill; (1) covering the entire pupa.
Adult - male

$\begin{array}{lll}6 & 0.16 & 0.00\end{array}$

Modified from character 12 of Gil-Azevedo and Maia-Herzog (2007: 43).

$\begin{array}{lll}8 & 0.25 & 0.70\end{array}$

Character 43 of Gil-Azevedo and Maia-Herzog (2007: 49).

$\begin{array}{lll}5 & 0.20 & 0.71\end{array}$

Modified from character 9 of Coscarón and Coscarón-Arias (1997: 114) and character 45 of Gil-Azevedo and Maia-Herzog (2007: 49).

$3 \quad 0.50 \quad 0.92 \quad$ Character 8 of Coscarón and Coscarón-Arias (1997: 114) and 46 of Gil-Azevedo and Maia-Herzog (2007: 49).

$2 \quad 0.50 \quad 0.92$

$5 \quad 0.20 \quad 0.60$ Cited by Coscarón (1991).
Pupa

$9 \quad 0.33 \quad 0.53$

$1 \quad 1.00 \quad 1.00$

$12 \quad 0.66 \quad 0.50$

$\begin{array}{lll}6 & 0.16 & 0.00\end{array}$

$2 \quad 0.50 \quad 0.92$

$2 \quad 1.00 \quad 1.00$

uninformative

$\begin{array}{lll}5 & 0.20 & 0.20\end{array}$

$2 \quad 0.50 \quad 0.90$

$\begin{array}{lll}6 & 0.33 & 0.76\end{array}$

$5 \quad 0.20 \quad 0.60$

$2 \quad 0.50 \quad 0.85$
Cited by Coscarón (1987).

Cited by Coscarón (1991)

Modified from character 12 of Coscarón and Coscarón-Arias (1997: 114).

Modified from character 12 of Coscarón and Coscarón-Arias (1997: 114)

Cited by Gil-Azevedo et al. (2005).

Cited by Gil-Azevedo et al. (2005).

Cited by Gil-Azevedo et al. (2005).

Character 44 of Adler et al. (2004: 135) and 75

of Gil-Azevedo \& Maia-Herzog (2007: 53).

Character 89 of Gil-Azevedo and Maia-Herzog (2007: 54).

Cited by Gil-Azevedo et al. (2005).

Character 178 of Adler et al. (2004: 154) and

91 of Gil-Azevedo and Maia-Herzog (2007: 55).

Character 10 of Coscarón and Coscarón-Arias (1997: 114). 
Characters and states (1) negative, dark background.

39 Antenna, segment 1, length ratio: (0) longer than 2; (1) equal to or smaller than 2.

40 Antenna, segment 3, length ratio: (0) equal to or shorter than 2; (1) longer than 2.

41 Hypostoma, anterior margin shape: (0) straight; (1) concave.

42 Hypostoma, para-lateral teeth: (0) present; (1) absent.

43 Hypostoma, hypostomal setae, number: (0) $7+7$ or less; (1) $8+8$; (2) $10+10$ or more.

44 Postgenal cleft, shape: (0) subtriangular; (1) oval; (2) subsquare.

45 Abdomen, $1+1$ ventral tubercles: (0) absent; (1) present.

\section{L $\quad$ CI RI}

Larva

$\begin{array}{lll}4 & 0.25 & 0.66\end{array}$

$3 \quad 0.33 \quad 0.33$

$5 \quad 0.20 \quad 0.50$

$\begin{array}{lll}4 & 0.25 & 0.50\end{array}$

$2 \quad 0.50 \quad 0.50$

$\begin{array}{lll}6 & 0.33 & 0.55\end{array}$

$\begin{array}{lll}7 & 0.28 & 0.64\end{array}$

$2 \quad 0.50 \quad 0.85$
Summary

Cited by Crosskey (1990)

Character 98 of Gil-Azevedo and Maia-Herzog (2007: 56).

Modified of character 99 of Gil-Azevedo and Maia-Herzog (2007: 56).

Character 162 of Adler et al. (2004: 153).

Character 50 of Adler et al. (2004: 163) and

104 of Gil-Azevedo and Maia-Herzog (2007: 58).

Cited by Coscarón (1991).

Character 109 of Gil-Azevedo and Maia-Herzog (2007: 58).

Character 113 of Gil-Azevedo and Maia-Herzog (2007: 58).

$a$ : here we considered all the armed cibarium homologous, but there are some structural and teeth distribution differences that should be better observed in the future. In our analysis the cibarium distinctly armed appears three times independently: Simulium (Inaequalium) + Simulium (Psaroniocompsa), Simulium (Ectemnaspis) + Simulium (Psilopelmia) and Simulium (Trichodagmia); b: Simulium dekeyseri, Simulium pertinax, Simulium serranum and Simulium spinibranchium have an intermediate cocoon that sometimes appears as slipper-shaped and other as boot-shaped. In this case we coded those species with both states. Simulium bifenestratum that has a bizarre cocoon and was treated as inapplicable for this character; CI: consistency index; L: length; RI: retention index. 
Data matrix for the cladistic analyses

\begin{tabular}{|c|c|c|c|c|c|c|c|c|c|c|c|c|c|c|c|c|c|c|c|c|c|c|c|c|c|c|c|c|c|c|c|c|c|c|c|c|c|c|c|c|c|c|c|c|c|}
\hline & & & & & & & & & & 1 & & & & & & & & & & 2 & & & & & & & & & & 3 & & & & & & & & & & & & & & & \\
\hline & 1 & 2 & 3 & 4 & 5 & 6 & 7 & 8 & 9 & 0 & 1 & 2 & 3 & 4 & 5 & 6 & 7 & 8 & 9 & 0 & 1 & 2 & 3 & 4 & & 6 & 7 & 8 & 9 & 0 & 1 & 2 & 3 & 4 & & & 7 & & 9 & 0 & 1 & 2 & & 4 & \\
\hline etacne & 0 & 0 & 1 & 0 & 0 & 0 & 0 & 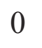 & - & 0 & 0 & 0 & 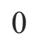 & 0 & 0 & - & 0 & 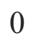 & 0 & 0 & 2 & 1 & 0 & 0 & & 0 & 0 & 7 & & & & ( & 0 & 1 & & & 0 & & 1 & & & 0 & & & \\
\hline - h & 0 & 0 & 0 & 0 & 0 & 0 & 1 & 0 & 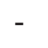 & 0 & & & 0 & 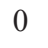 & & - & 0 & & 0 & & & 1 & 0 & & & 0 & 0 & & & & & & & 0 & & & 0 & & 1 & & & 0 & & & \\
\hline & 0 & 0 & 0 & 0 & 0 & 0 & 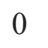 & 0 & - & 0 & 0 & 0 & 0 & 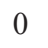 & & - & s & & 0 & & 0 & 1 & & 0 & & 0 & 0 & & & & & & 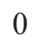 & 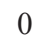 & & & 0 & & 1 & & & 0 & & & \\
\hline & 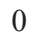 & 2 & 0 & 1 & 0 & 0 & 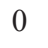 & 1 & 1 & 0 & 0 & 1 & 1 & 0 & & - & 0 & & 0 & & & 1 & 0 & 0 & & 1 & . & 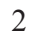 & & & 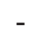 & 0 & 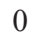 & 0 & & 1 & 0 & & 1 & ) & & 0 & & & \\
\hline 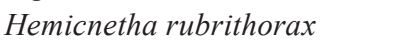 & ( & 0 & 0 & 1 & 0 & 1 & 1 & 1 & 1 & 0 & 0 & 0 & 1 & 1 & & 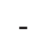 & 1 & 0 & 0 & & & 1 & 0 & & & 0 & 0 & 3 & & & & 0 & 1 & 1 & & & 1 & & 1 & & & 1 & & & \\
\hline 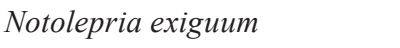 & & 1 & 1 & 0 & 0 & 0 & 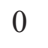 & 0 & & 1 & 1 & 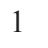 & 1 & 0 & & 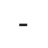 & 1 & & 1 & & c & 0 & 1 & 0 & & 2 & -5 & $J$ & & & 0 & -5 & 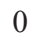 & t & & & 0 & & 1 & & & 0 & & 1 & \\
\hline & & & 0 & 1 & & 0 & 0 & & & 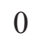 & & & 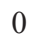 & 0 & & - & 0 & & & & & & 0 & & & & 0 & 0 & & & & 0 & & 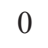 & & & 0 & & & & & 0 & & & \\
\hline$P s c$ & 1 & 1 & 1 & 1 & 1 & 0 & 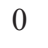 & 1 & 1 & 0 & 1 & 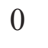 & 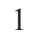 & 0 & 0 & 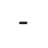 & 0 & ( & 1 & & c & 1 & 0 & 0 & & 1 & 然 & $J$ & & & & 0 & 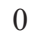 & 0 & & 0 & 0 & & 1 & & & 0 & & 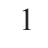 & \\
\hline & ( & & 0 & 1 & 1 & 0 & 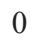 & & & 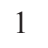 & 0 & 1 & 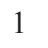 & ( & 0 & - & 0 & & 1 & & & 年 & 0 & & & 1 & 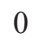 & 0 & & & - & 0 & & 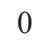 & & & 0 & & & 1 & & 0 & & 1 & \\
\hline & $c$ & 1 & 0 & 1 & 1 & 0 & 0 & 1 & _ & 1 & 0 & 0 & 1 & & & - & & & & & ( & & ) & & & & 0 & $2+2+$ & & & - & & & ) & & & & & 0 & & & 0 & & & \\
\hline & & 1 & 0 & 1 & 1 & 0 & 0 & 1 & 1 & 0 & 0 & & 1 & 0 & & - & 0 & & 1 & & & 1 & 0 & & & 1 & 0 & 1 & & & 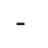 & & & 0 & & & 0 & & & . & & 0 & & & \\
\hline & & & 0 & 1 & 1 & 0 & 1 & & - & 0 & 1 & & 0 & & & 0 & 1 & & & & & & & & & & & 3 & & & 0 & & & ) & & & & & 1 & & & & & & \\
\hline & & 1 & 0 & 1 & 1 & 0 & 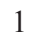 & & - & 0 & 1 & 0 & 0 & 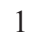 & & 0 & 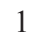 & & ( & & & & 0 & & & 1 & 0 & 3 & & & 0 & & & 0 & & & 0 & & 1 & & & 0 & & & \\
\hline & & & 0 & 1 & 1 & 0 & 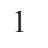 & & - & 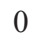 & & & 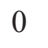 & 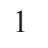 & & 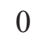 & 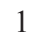 & & 0 & & & & 0 & & & 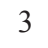 & 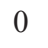 & 3 & & & 0 & & & ) & & & & & 1 & & & 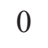 & & & \\
\hline & ( & 1 & 0 & 1 & 1 & 0 & 1 & 1 & 1 & 0 & 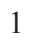 & 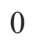 & 1 & 1 & 2 & 1 & 1 & & 0 & & & & 0 & & & 0 & 0 & 3 & & & 0 & & 0 & 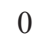 & & & 0 & & 1 & ? & & 0 & & 1 & \\
\hline & & 0 & 0 & 0 & 0 & 0 & 0 & & 1 & 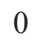 & 0 & & 1 & 0 & 1 & - & 0 & & 0 & & c & & 0 & ( & & 1 & 政 & 3 & & & 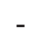 & 0 & & 0 & & & 0 & & 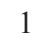 & 0 & & 0 & & & \\
\hline Pte & & 0 & 0 & 0 & 0 & 0 & 0 & 1 & 1 & 0 & 0 & 0 & 1 & 0 & 1 & 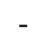 & 0 & & 0 & & 0 & 0 & 0 & 0 & & & 0 & 3 & & & 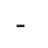 & ) & 0 & 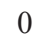 & & & & & 1 & & & 0 & & & \\
\hline tale & ( & 2 & 0 & 1 & 1 & 1 & 0 & 0 & - & 1 & 0 & 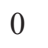 & 0 & 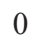 & 1 & - & 0 & & 1 & & 2 & 1 & 0 & 0 & & 0 & 0 & 6 & 0 & & - & 0 & 0 & 1 & 0 & U & U & - & 1 & 0 & & 0 & & 1 & \\
\hline & & 2 & 0 & 1 & 1 & 1 & 0 & 1 & - & 0 & & & 0 & 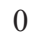 & 1 & - & 0 & & 1 & & & & & & & 2 & 0 & 7 & & & - & & & 1 & & & 0 & & 1 & & & 0 & & & \\
\hline & 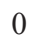 & 0 & 0 & 1 & 0 & 1 & 0 & 1 & 1 & 0 & 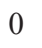 & 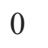 & 1 & 0 & 1 & - & 0 & 1 & 0 & & 1 & 1 & 0 & 0 & & 0 & 0 & 0 & 0 & - & - & 0 & 1 & 1 & 0 & 0 & 0 & 0 & 1 & $?$ & 0 & 0 & 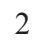 & 1 & \\
\hline & & 1 & 1 & 0 & 0 & 0 & 0 & 1 & 1 & 0 & 1 & 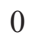 & 0 & 1 & 2 & 0 & 1 & ( & 0 & 0 & & 1 & 1 & 1 & & 2 & 0 & 2 & & & 0 & & 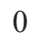 & 0 & & & 0 & & 1 & . & & 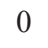 & & & \\
\hline & ( & 1 & 0 & 0 & 0 & 0 & 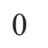 & 1 & 0 & 0 & 0 & 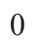 & 0 & 0 & 2 & - & 1 & 0 & 0 & 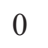 & 1 & 0 & 1 & 1 & & 2 & 1 & 4 & 1 & 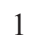 & 2 & 0 & 0 & - & 0 & 1 & 1 & 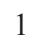 & 1 & 0 & 1 & 0 & 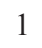 & 0 & \\
\hline & & 1 & 1 & 0 & 0 & 0 & 1 & 1 & 0 & 0 & 0 & ( & 0 & 0 & 2 & 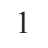 & 1 & 0 & 0 & 1 & 1 & 0 & 1 & 1 & & 2 & 1 & 4 & 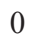 & & 2 & 0 & 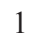 & 1 & & & 1 & 1 & 1 & 0 & & 1 & 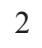 & & \\
\hline & & & 1 & 0 & 0 & 0 & 0 & 1 & 0 & 0 & 0 & & 0 & 0 & 2 & 0 & 1 & & 0 & & & 0 & 1 & 1 & & 0 & 1 & 3 & . & 1 & 0 & 1 & 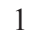 & 1 & & & 1 & & 1 & 0 & & 0 & 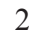 & 0 & \\
\hline & 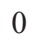 & 1 & 0 & 0 & 0 & 0 & 0 & 1 & 1 & 0 & 0 & 0 & 0 & 0 & 2 & 0 & 1 & 0 & 0 & 0 & 1 & 0 & 1 & 1 & 0 & 2 & 0 & 5 & 0 & ( & - & 0 & 0 & 1 & 2 & 1 & 1 & 0 & 1 & 0 & 0 & 0 & 1 & 0 & \\
\hline & & 1 & 0 & 0 & 0 & 0 & 0 & 1 & 1 & 0 & & & 0 & 0 & & 0 & 1 & & 0 & & & & & 1 & & 2 & 0 & 1 & & & 0 & & & 1 & & & 1 & & 0 & 1 & & 0 & & & \\
\hline & 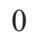 & 1 & 0 & . & 0 & 0 & 0 & 1 & 1 & 0 & 0 & 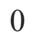 & 0 & 0 & 2 & 0 & 1 & 0 & 0 & 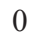 & 0 & 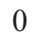 & 1 & 1 & & 2 & 0 & s & 1 & 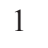 & 0 & 0 & 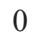 & $\mathbf{a}$ & 0 & 0 & 0 & 1 & 1 & 0 & 0 & 0 & 0 & 0 & \\
\hline & & 1 & 1 & 0 & 0 & 0 & 0 & 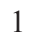 & 0 & 0 & & & 0 & 0 & 2 & 0 & 1 & & 0 & & & 0 & & 1 & & 2 & 0 & 8 & & 然 & 0 & 0 & 0 & 1 & 2 & & 1 & & 1 & 0 & & 0 & & 0 & \\
\hline Chi & 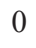 & 1 & 0 & 0 & 0 & 0 & 1 & 1 & 1 & 0 & 1 & ( & 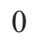 & 1 & 2 & 0 & 1 & 0 & - & 0 & 2 & 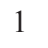 & 1 & 1 & & 2 & 0 & 3 & 1 & 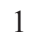 & 0 & 0 & 0 & 0 & 1 & 0 & 0 & 0 & 1 & 1 & & 0 & 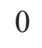 & 1 & \\
\hline & & 1 & 0 & 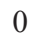 & 0 & 0 & 0 & 1 & 0 & 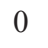 & 0 & & 0 & 0 & 2 & 0 & 1 & 0 & 0 & & & 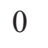 & & 1 & & 2 & 0 & 3 & 1 & 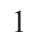 & 0 & 0 & $\rho$ & $\mathbf{a}$ & 0 & 0 & 0 & 1 & 1 & 0 & & 0 & 1 & 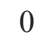 & \\
\hline Chir & 0 & 1 & 0 & 0 & 0 & 0 & 0 & 1 & 0 & 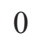 & 0 & t & 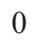 & 0 & 2 & 1 & 1 & 0 & 0 & 0 & & c & & 1 & & 2 & 1 & 4 & 1 & 2 & 1 & 0 & 0 & 1 & 2 & & 1 & & 1 & 0 & & 1 & & 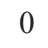 & \\
\hline & & 1 & 0 & 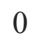 & 0 & 0 & U & 1 & 1 & 0 & 0 & 0 & 0 & 0 & 2 & 0 & 1 & 0 & 0 & 0 & 0 & 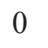 & & 1 & & 2 & 0 & 3 & 1 & 1 & 0 & 0 & 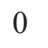 & $\mathbf{a}$ & 0 & $\left(\mathrm{C}-\mathrm{C}^{-}\right)$ & 0 & 1 & 1 & 1 & & 0 & & P & \\
\hline inibrans & 0 & 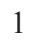 & 0 & 0 & ( & 0 & 0 & 2 & 1 & 0 & 然 & 0 & 0 & 0 & 2 & 0 & 1 & ( & 0 & 1 & 0 & 0 & & 1 & & 2 & 0 & 3 & 0 & 1 & 0 & 0 & 1 & $\mathbf{a}$ & 0 & ( & 0 & 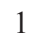 & 1 & 1 & 0 & 0 & 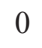 & 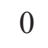 & \\
\hline Chirostilbia subpallidum & 0 & 1 & 1 & 0 & 0 & 0 & 1 & 1 & 1 & 0 & 1 & 0 & 0 & 1 & 2 & 0 & 1 & & 0 & 1 & 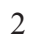 & 1 & & 1 & & 2 & 0 & 3 & & 1 & 0 & 0 & 0 & 0 & 1 & & 0 & & 1 & 1 & & 0 & & & \\
\hline
\end{tabular}

A: 0\&1; -: inapplicade data; ?: unavailable. 